\title{
The missing link between overtourism and post-pandemic tourism. Framing Twitter debate on the Italian tourism crisis
}

\author{
Cecilia Pasquinelli and Mariapina Trunfio \\ Department of Management and Quantitative Studies, \\ University of Naples - Parthenope, Napoli, Italy
}

\begin{abstract}
Purpose - This paper aims to exploit existing tourism knowledge to frame the unprecedented pandemic tourism crisis, its key aspects and impacts on the tourism industry. It builds a conceptual bridge and discusses the opportunity to capitalise on the missing link between the pre-COVID overtourism and the postCOVID "undertourism" debates.

Design/methodology/approach - A cross-fertilisation between the overtourism knowledge and the emerging COVID-19 literature stream is proposed and supported by an online media analysis focussing on the Italian tourism debate on Twitter. A text analysis of 2,500 posts helps discuss the conceptual framework.

Findings - The analysed Twitter debate prioritised socio-economic impacts, regulative actions and the recovery approach, representing government as the pivotal actor to overcome the pandemic crisis. An integrative interpretative framework results from this research, opening three areas of inquiry, such as the recovery-reform continuum, managerial approaches beyond regulative frames of action and a critical sizing of digital technologies deployment.

Research limitations/implications - Samples with different geographical and temporal coverage may provide further and multifaceted insights into the emerging tourism online media debate.

Originality/value - An original conceptualisation counter-intuitively frames post-pandemic tourism scenarios. Additional elements of originality are the online media analysis contributing to the emerging COVID-19 agenda and the use of Twitter social platform to investigate the tourism debate.
\end{abstract}

Keywords Italy, Twitter, Overtourism, Online media, COVID-19 crisis, Post-pandemic tourism

Paper type Research paper

\section{Introduction}

The COVID-19 crisis casts new light on the role and impacts of tourism, which is one of the industries most affected by globally reduced mobility and physical distancing. In the current crisis, transformative effects on the tourism industry were said unavoidable with durable consequences for revenues and employment (Gossling et al., 2020). The COVID-19 crisis boosted critical reflections on the resilience of tourism systems and their adaptation to

(C) Cecilia Pasquinelli and Mariapina Trunfio. Published by Emerald Publishing Limited. This article is published under the Creative Commons Attribution (CC BY 4.0) licence. Anyone may reproduce, distribute, translate and create derivative works of this article (for both commercial and non-commercial purposes), subject to full attribution to the original publication and authors. The full terms of this licence may be seen at http://creativecommons.org/licences/by/ 4.0/legalcode

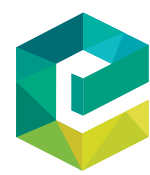

Journal of Place Management and Development Vol. 15 No. 3,2022 pp. $229-247$ Emerald Publishing Limited 1753-8335 DOI 10.1108/JPMD-07-2020-0073 
JPMD

15,3

global change (Gossling et al., 2020), whereas expectations of "unforeseen trajectories instead of historical trends" cast doubts on the capacity of consolidated frameworks to explain tourism phenomena (Sigala, 2020).

The sudden contraction of international and national tourist arrivals dramatically changed the tourism scenarios: from overtouristified destinations and destinations at risk of overtourism to "ghost towns" and empty destinations. Media have circulated images of unrecognisably deserted cities as if crowded streets and squares had been part of their place identity. "From overtourism to undertourism" (Qualitytravel, 2020; Johnston, 2020) is the summary of such change, which has circulated through media and echoed the need for public interventions to support and relaunch tourism experiencing new circumstances.

Until the current COVID-19 pandemic outbreak, scholars, policymakers and practitioners had been increasingly concerned with overtourism, following the continuously growing numbers of international tourists, crowding and congestion. The term "overtourism" catalysed critical attention towards tourism growth models, as a form of renewed awareness and interest for the impacts of tourism on the hosting territories and their spatial, social and cultural degradation.

The dramatic pandemic evolution, bringing new tourism issues, challenged the consolidated theoretical frameworks (Gossling et al., 2020; Sigala, 2020). These have limitations in framing "wicked problems", which are not fully described, whose evolution is highly uncertain (Phi, 2019), and for which possible solutions have not been experimented yet (Schweinsberg et al., 2017). In the face of wicked problems, the online media debate provides meaningful narratives that, shaping public opinion and influencing decision makers and their agendas (Phi, 2019; Pasquinelli and Trunfio, 2020a; Schweinsberg et al., 2017), may help frame tourism role, issues and impacts.

This exploratory paper aims to exploit existing tourism knowledge to frame the unprecedented pandemic tourism crisis, its key aspects and impacts on the tourism industry. It frames the Italian tourism debate on Twitter by cross-fertilising the overtourism knowledge with the emerging COVID-19 literature. Twitter is a social platform particularly suitable for investigating public debate on news daily covered by media and newsworthy events (Bruns and Burgess, 2012). Building on the emerging academic debate calling for a resetting of consolidated tourism research, this paper discusses the opportunity to capitalise on the missing link between pre-COVID overtourism and post-COVID "undertourism" debate to open areas of inquiry on future tourism developments.

The paper is structured as follows. The first section discusses the advancements in the overtourism debate, whereas the second theoretical section frames emerging issues in the post-pandemic tourism literature. The empirical study is introduced, outlining the process of the online media analysis and explaining the motivations for focusing on the Italian tourism debate. Findings are discussed by juxtaposing the overtourism knowledge, the academic perspectives on tourism post-pandemic evolution and the empirical insights into the post-COVID tourism debate on Twitter. Their discussion leads to opening areas of further inquiry, such as the recovery-reform continuum, managerial approaches beyond regulative frames of action and a critical sizing of digital technologies deployment.

\section{Overtourism: what did we learn?}

Overtourism is part of the sustainable tourism research agenda, and it was said "old wine in new bottles" debate (Dredge, 2017). Although tourism growth-related issues were not a novelty (Capocchi et al., 2019), some distinctive characteristics of the overtourism 
phenomenon emerged in the recent debate. Overtourism was said to reshape economic, physical and social urban landscapes (Peeters et al., 2018; Koens et al., 2018; Seraphin et al., 2018) and to hardly impact residents' quality of life (Cheer et al., 2019; Cheung and Li, 2019; Dodds and Butler, 2019; Novy and Colomb, 2019). Tourism phobia and anti-tourism emerged in various urban contexts (Colomb and Novy, 2017; Milano, 2017).

From signalling the quantitative excess of tourists gathering in global destinations (Muler Gonzalez et al., 2018), the concept of overtourism was increasingly connected to the permanent change in local life, to the impact on people's sense of place and to the limited Italian tourism crisis economic gains for locals outweighed by the costs of exploitative and impactful forms of tourism (Cheer et al., 2019).

The characteristics of the phenomenon were defined as overcrowded public spaces, pervasive visitor impact because of inappropriate behaviours, the physical touristification of city centres and other highly visited areas and the displacement of residents from urban residential areas caused by Airbnb and similar platforms that exacerbate touristification and gentrification (Koens et al., 2018).

Three analytical dimensions were proposed to outline and size overtourism, such as the factual, behavioural and perceptual dimensions, representing different facets of the same phenomenon (Pasquinelli and Trunfio, 2020a). A syncretic view of the literature framed overtourism not just as a quantitative (high and increasing number of tourists) but also as a qualitative phenomenon, based on the coexistence of the factual, behavioural and perceptual dimensions.

The factual dimension refers to the congestion of spaces and facilities (including traffic congestion), rising costs of living (with particular attention to renting and housing costs in overtouristified areas), litter and noise (Dodds and Butler, 2019). The behavioural dimension focusses on various stakeholders' behaviours (e.g. tourists, retailers and residents), including the tourists' pervasiveness and misbehaviours, residents' moving out from central areas, anti-tourism attitude, fears and a sense of irritation for tourists (Novy and Colomb, 2019). The third dimension (i.e. the perceptual) draws attention to the subjective side of the tourism impacts (meaning the perceived impacts), as confirmed by extensive literature (Rosenow and Pulshipher, 1979; Teye et al., 2002; Yeh, Wai Aliana and Zhang, 2012; Rasoolimanesh and Jaafar, 2016; Rasoolimanesh et al., 2017; Goodwin, 2017; Latip et al., 2018; Oklevik et al., 2019). This dimension refers to the perceptions of overtourism and overtouristified destinations, which damage the destination brand, with a consequent decrease in the perceived value of the tourism experience and the perceived quality of life among residents.

The overtourism debate took into account the need and the opportunity to actively deal with this phenomenon and the related impacts. Three potentially coexisting approaches emerged in the literature such as regulation, management and marketing (Pasquinelli and Trunfio, 2020b; Trunfio and Pasquinelli, 2021). The regulatory approach is based on the enforcement of political institutional power to impose rules (de la Calle-Vaquero et al., 2020), taxes and restrictions and incentives to boost tourism in connection with broader urban policies. The managerial approach is based on processes and organisation frameworks to shape and give direction to destination development, without imposing limits and normative schemes. Finally, the marketing approach focusses on the sharing and delivery of the tourist product and experience value, for instance, through communication and critical social media marketing (Font and McCabe, 2017).

The overtourism literature discussed several actions that fit into the three mentioned approaches. A regulative rationale underlies residents' compensation for tourism burdens (e.g. tourist taxes; Peeters et al., 2018); the managerial approach underlies tourist dispersal 
JPMD

15,3

strategies through the design of alternative tourism products (Peeters et al., 2018; UNWTO, 2018), tourist flows optimisation (Oklevik et al., 2019), infrastructure improvements to reduce tourist pressure (Koens et al., 2018), favouring local employment and community engagement to reduce local conflicts (Postma and Schmuecker, 2017). The marketing approach concerns the rebranding of destinations (Seraphin et al., 2019a) and communitybased festivals to build positive relationships between residents and tourists (Seraphin et al., 2019 b).

Technological tools were said to play a role. If UNWTO (2018) outlined a specific set of ICT tools for addressing overtourism (i.e. real-time technologies, travel cards, apps to boost dispersal, dynamic pricing and virtual reality, social media used by locals to promote alternative visits and sites, Web circulation of traffic, parking and facilities information and big data analysis), scholars highlighted the importance of interpreting overtourism within the broader framework of urban sustainable development by entangling the technological side of the smart city together with human and social capital dimensions (Koens et al., 2019; Pasquinelli and Trunfio, 2020b).

The analytical dimensions and the actions cast light on the coexistence of a large set of actors that take part in the overtourism phenomenon, playing either an active or passive role (Pasquinelli and Trunfio, 2020b). An understanding of the tourism model that these different actors (public and private actors) bear in their minds (informing them about tourism role, shapes and effects) constitutes the third pillar of the overtourism debate, revealing the mental model that underlies actors' behaviours and actions and, consequently, influences tourism development trajectory.

The overtourism literature evolved into a deeper discussion of the tourism models, which are understood as the rationale for interventions and actions, and contribute to giving shape to the visible tourism impacts (analytical dimensions), which can be observed and analysed. This conceptualisation helps move beyond the mere description of the phenomenon.

Conservative views versus radical rethinking and reformative approaches to tourism development emerged in the overtourism debate. The conservative logic is grounded on the tourism-led growth hypothesis (Brida et al., 2014) and aims to mitigate the negative impacts of tourism by adopting technical solutions and maintaining the "business as usual" (Dwyer, 2017). This is based on the vital role of the tourist inflow size to maintain visitors' expenditure and on-site consumption economically significant. The underlying vision is to further boost tourist growth which, in this case, represents the key parameter for measuring local tourism performance. On the other hand, the "degrowth imperative" was discussed (Higgins-Desbiolles et al., 2019; Cheung and Li, 2019), pointing towards radical transformative responses in the face of tourism challenges (Milano, Novelli, and Cheer, 2019). This represents a radical vision on tourism development, drawing attention to a stronger integration of tourism with local development and planning in the pursuit of the local community's well-being.

\section{Post-pandemic tourism: Emerging issues in the COVID-19 agenda}

Significant attention has been drawn to the pandemic impacts on tourism economies and the social costs intrinsic to the loss of jobs and income following global tourist flows shrinkage and travelling limitations. Sophisticated approaches to measuring the pandemic effects and to comparing the impacts in different contexts (Karabulut et al., 2020; Uğur and Akbiyik, 2020; Sharma and Nicolau, 2020) were discussed, and forecast models of the international tourism demand were designed to size the potential long-term effects on local economies (Fotiadis et al., 2021). Structural effects were hypothesised on the vacation rental market, 
suggesting that COVID-19 may have "disrupted the disruptor" (i.e. Airbnb) (Dolnicar and Zare, 2020), even though no evidence for such structural effects could be produced.

COVID-19 impacts on tourists' behaviours is a crucial topic (Matiza, 2020), and some evidence on post-pandemic planned travel behaviours was collected, suggesting a significant change in travelling intentions, attitude (Li et al., 2021) and risk aversion (Zhang et al., 2020). For instance, private transports replaced public transports in tourists' preferences, with the potential future strengthening of traffic and transport infrastructure issues (Li et al., 2021). Protective and cautious travel behaviours are the emerging traits of Italian tourism future travellers (Zheng et al., 2021) and loyal tourists should be prioritised for their likely intention to revisit those destinations with a solid reputation and inspiring trust (Hassan and Soliman, 2021).

Perceived risks (Matiza, 2020; Sánchez-Cañizares et al., 2020), "travel fear" (Zheng et al., 2021) and "fear arousal" moderate the intention to revisit a destination (Hassan and Soliman, 2021). From an evolutionary psychology perspective, COVID-19 effects on tourists' psyche should not be overlooked (Kock et al., 2020): disease avoidance motives and negative crowding perceptions deserve particular attention. Individuals tend to adapt to health threats by developing negative feelings for crowded environments, whereas group travel preferences, travel insurance and a sense of loyalty for specific localities seem to boost perceptions of security (Kock et al., 2020).

From a perceptual perspective, residents' risk perceptions were in focus too. Perceived social costs of tourism activities in the pandemic crisis, related to the public health threat and pressure on the local health-care system, were quantified by sizing residents' willingness to pay for risk reduction (Qiu et al., 2020).

Attention was also paid to actions and policies adopted to face the pandemic challenges. Marketing approaches have been considered fundamental to support tourism relaunch, and much research has focussed on the factors driving tourists' intention to travel in the pandemic context for providing inputs to marketing strategy design (Sánchez-Cañizares et al., 2020). Recovery marketing and destination media profiling were said to be part of those crucial actions mitigating the pandemic impacts, for dealing with the perceived risk highly influencing domestic and international tourists' decision to travel (Matiza, 2020). Recovery marketing (Campiranon and Scott, 2014 cited in Matiza, 2020) may reassure tourists about safety and local crisis management capabilities. Crisis communication was said to be critical for establishing an "emotional attachment" with tourists experiencing fears and anxiety (Hang et al., 2020). Destination media profiling is important to respond to the increasing information seeking during a crisis (Matiza, 2020).

Although the technology was fairly overlooked in the first phase of development of the COVID-19 research agenda, transformative e-tourism research was suggested (Gretzel et al., 2020), and technology was identified as potentially laying at the core of several solutions. Critical and fresh insights into technology deployment purpose, applications and implications are highly needed (Sigala, 2020).

Stimulus packages offered to tourism businesses and workers were analysed, such as tax incentives, postponement of bank repayment and discounts on utility bills (Foo et al., 2020). Structural analysis of national strategies responding to the COVID-19 crisis revealed that much emphasis was on impact mitigation policies and on the actions to accelerate the recovery of the industry. Only one case out of the seven analysed countries included interventions boosting tourism systems to "prepar[e] for tomorrow" (Collins-Kreiner and Ram, 2020).

The need for broader measures to sustain tourism was argued. Attention is to be paid not only to tourism businesses and workers in the recovery process but also to residents in 
JPMD 15,3

tourist localities for their changing perceptions of public health risks connected to tourism (Qiu et al., 2020). A "holistic and innovative mindset", instead of short-sighted tourism recovery, is needed (Qiu et al., 2020); that is, the approaches adopted in previous health emergencies should be overcome, even though the emerging signals from the current pandemic context seem to confirm these.

Beyond policies and interventions, part of the COVID-19 agenda raised a clear point: we need to reframe the tourism models, which are crucial as underlying and informing actions. A "transformational opportunity" (Sigala, 2020) was outlined to go out of the crisis, bringing the need to overcome the consolidated tourism models which are not adequate to envision the tourism future (Gossling et al., 2020). The tourism development models in the minds of policymakers should be under scrutiny because through incentives, subsidies and investments, they will drive tourism evolution out of the pandemic crisis, carrying on high risk of boosting the re-establishment of pre-COVID disequilibria (Iannides and Gyimothy, 2020).

In this regard, a "recovery versus reform" dilemma is suggested in the literature, warning about how the legitimate search for rapid recovery may, however, be in contrast with tourism reformation (Higgins-Desbiolles, 2021) and with the emergence of innovative tourism mindsets. Sustainable, ethical and responsible tourism keeps representing the ideal goal of tourism development in the pandemic turn (Higgins-Desbiolles, 2021), but the "old" challenge of putting the concept into practice does remain salient (Hunter, 1997; Garrod and Fyall, 1998).

\section{Research design}

An explorative analysis of the Italian tourism debate on Twitter was designed, to empirically ground the conceptual link between pre-COVID overtourism and post-pandemic tourism agendas.

The Italian context was selected for various reasons. Italy was the first country to make the spread of coronavirus emerge outside of Asia and a lockdown policy followed a fastgrowing number of confirmed cases and deaths, anticipating the other European countries in the first wave of contagion in early 2020. Secondly, the pandemic impacts were particularly visible in a country where the tourism industry represented around $13 \%$ of national GDP (Bank of Italy, 2018) and accounted for 7\% of national workers (Istat, 2020). Estimates stated $-68.6 \%$ overnight stays in $2020,-47 \%$ arrivals in July and $-26 \%$ in August (on 2019), and more significant decreases were scored by large cities suffering the toughest pandemic impacts (e.g. Venice $-71.5 \%$ arrivals) (ENIT, 2020). Thirdly, there has been a lively media debate on tourism recovery in the Italian context. According to Google Trends, in Italy, the interest for "tourism" was higher in May-August 2020 than in the same months in 2018 and 2019 (84 on average in 2020; 64 in 2019 and 68 in 2018).

Twitter was selected for its role in hosting and nurturing debate on daily news and newsworthy events covered by media, giving voice to a rich diversity of tweet senders (Bruns and Burgess, 2012). This is an original perspective in tourism studies, considering that social media, including Twitter, are usually referred to for their contribution to destination branding (De Moya and Jain, 2013; Hays et al., 2013; Lalicic et al., 2020) and their impact on tourism stakeholders' engagement (Trunfio and Della Lucia, 2018).

Investigating the online media debate through Twitter represents an explorative attempt to frame post-pandemic tourism issues in a time when they persist in a state of "wicked problems" (Phi, 2019). The COVID-19 impacts on tourism have not been fully described and explained, their nature and potential evolution are disputed and, at this stage, many diverse possible solutions are discussed but have not been experimented yet (Schweinsberg et al., 2017). The post-pandemic tourism crisis, at the time of the analysis, has also catalysed significant 
media attention (Hall, 2003), and the proposed analysis is meant to give insights into the emerging tourism discourse.

The overtourism knowledge scheme (Figure 1), grounded in the literature, was adopted

Italian tourism to frame the online media debate on post-COVID tourism.

\section{Data collection and analysis}

Tweets were collected through Netlytic by introducing "tourism" as a search keyword (the crisis word turismo was used, and only posts in Italian were retrieved). Retweets were excluded from the search, to focus on posts adding comments and contents. The retrieved sample contained 2,500 tweets covering the period of time from 21 to 28 January 2021.

A text analysis of the post sample was carried out, looking at word frequency distribution through the tweet descriptions (excluding titles). Then, the analysis proceeded with the manual construction of categories, derived from the overtourism knowledge scheme (Figure 1). The analytical dimensions (i.e. factual, behavioural and perceptual), the actions and the tourism model framed the empirical analysis (Table 1).

The words with a frequency higher than ten were considered in the categorisation process, 440 words in total. Among these, prepositions and words with general meaning that could not be easily classified (e.g. all, after, this and less) were not positioned in any category. Any word was inserted only in one category. Navigating the posts allowed the researchers to clarify the meaning of the single word in light of the usage context.

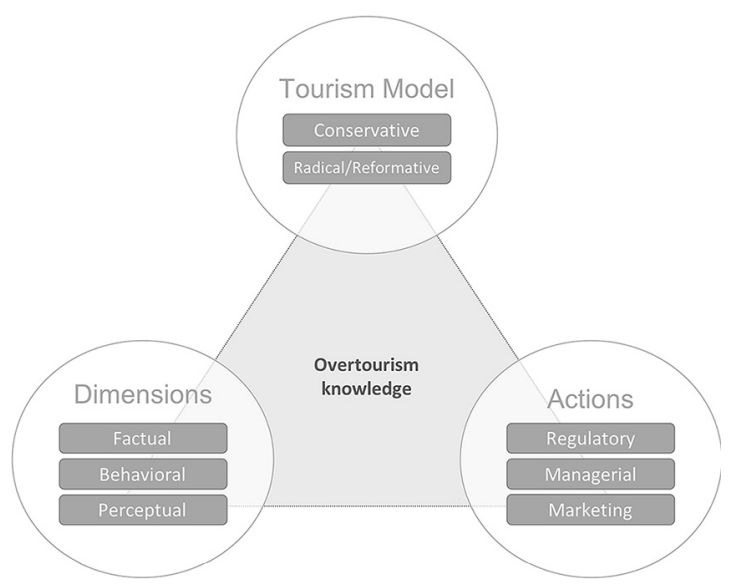

Figure 1.

Overtourism knowledge

\begin{tabular}{lll}
\hline Overtourism knowledge & Categories & \\
\hline Analytical dimensions & Factual & Keywords from Tweets \\
& Behavioural & (frequency $>$ 10) \\
Actions & Perceptual & \\
& Regulation & \\
Tourism models & Management & \\
& Marketing & \\
& Conservative & Radical/reformative \\
\hline
\end{tabular}

Table 1. Process of analysis 
JPMD

15,3

\section{Findings}

The Twitter debate revealed key aspects of the pandemic crisis and its impacts on the tourism industry. The analysis identified 91 keywords and grouped them in the eight categories of the overtourism knowledge (Table 1). According to their recurrent meaning in the posted texts, the keywords were clustered in the overtourism categories (Table 2), which were re-coded to give a more specific account of the correlated post-pandemic tourism themes.

The pandemic crisis was narrated as a phenomenon bringing significant socio-economic impacts (the factual dimension of the overtourism knowledge) on the tourism industry, affecting hospitality entrepreneurs, retailers, restaurants, as well as tourism workers and all actors connected with tourism economies, such as performing arts and entertainment (e.g. In Turin [...] entrepreneurs, retailers, tourism operators, 50,000 jobs and 13,000 firms at risk). The crisis reshaped travellers' attitude and behaviours (the behavioural dimension of the overtourism knowledge), pushing tourists to seek safe, green, slow and more responsible travelling modalities and experiences (e.g. slow tourism is the ideal way to travel). The pandemic crisis also boosted travelling risk perceptions (the perceptual dimension of the overtourism knowledge).

The urgent need for actions, to address and manage the socio-economic crisis, was frequently claimed. Subsidies and rescue packages were at the centre of the Twitter debate (regulative actions), such as financial supports, tax breaks for the economic actors to stand the crisis (e.g. urgent interventions to protect tourism firms and workers,); sanitary rules, protocols and standards to face the pandemic spread were also discussed from a regulation perspective. Additionally, projects redesigning tourism experiences and destination offering (managerial actions) and promotional campaigns to reactivate the demand (marketing actions) (e.g. new horizons for proximity tourism with a new platform for information and promotion [...]) were in focus.

Signals of interest for the tourism models (conservative and reformative) emerged from the analysis, highlighting different positions in the analysed online media debate. The keywords emphasised the need to save and restart tourism (e.g. Italian government: let's save tourism firms and workers before it's too late), as well as the need for transformative sustainable development (e.g. \#renewables, \#GreenTech, \#innovation and \#SmartMobility, new development models for \#experiential tourism).

Diverse actors were taken into consideration by the Italian online media debate on the post-COVID tourism crisis. According to the occurrences of the single keywords (Figure 2), government (the highest frequency) and minister/ministers were represented as active pivotal actors in charge of driving the tourism industry out of the pandemic crisis. Other actors were protagonists of tourism recovery in the Twitter debate, such as firms, in the hospitality industry and tourism-related sectors including technology providers (such as Google), workers and a national hospitality association (i.e. Federalberghi). They were represented as playing different roles in the post-pandemic evolution, either being hardly affected by the impacts of the crisis or laying at the core of the actions to move forward.

Table 3 provides examples of raw tweet fragments to give insights into the contents discussed in the analysed online media debate.

The eight post-pandemic tourism themes covered different percentages of the total number of posts, revealing their different weights in the Twitter debate (Figure 3). Attention to socio-economic impacts and the impacted actors (e.g. workers and tourism businesses) prevailed (36\% posts concerned this theme) in the sampled tweets. Subsidies and rescue packages followed in terms of relevance, referring to the actions needed or put in place to face the crisis ( $20 \%$ posts) and to the role of government. The government was a key actor 


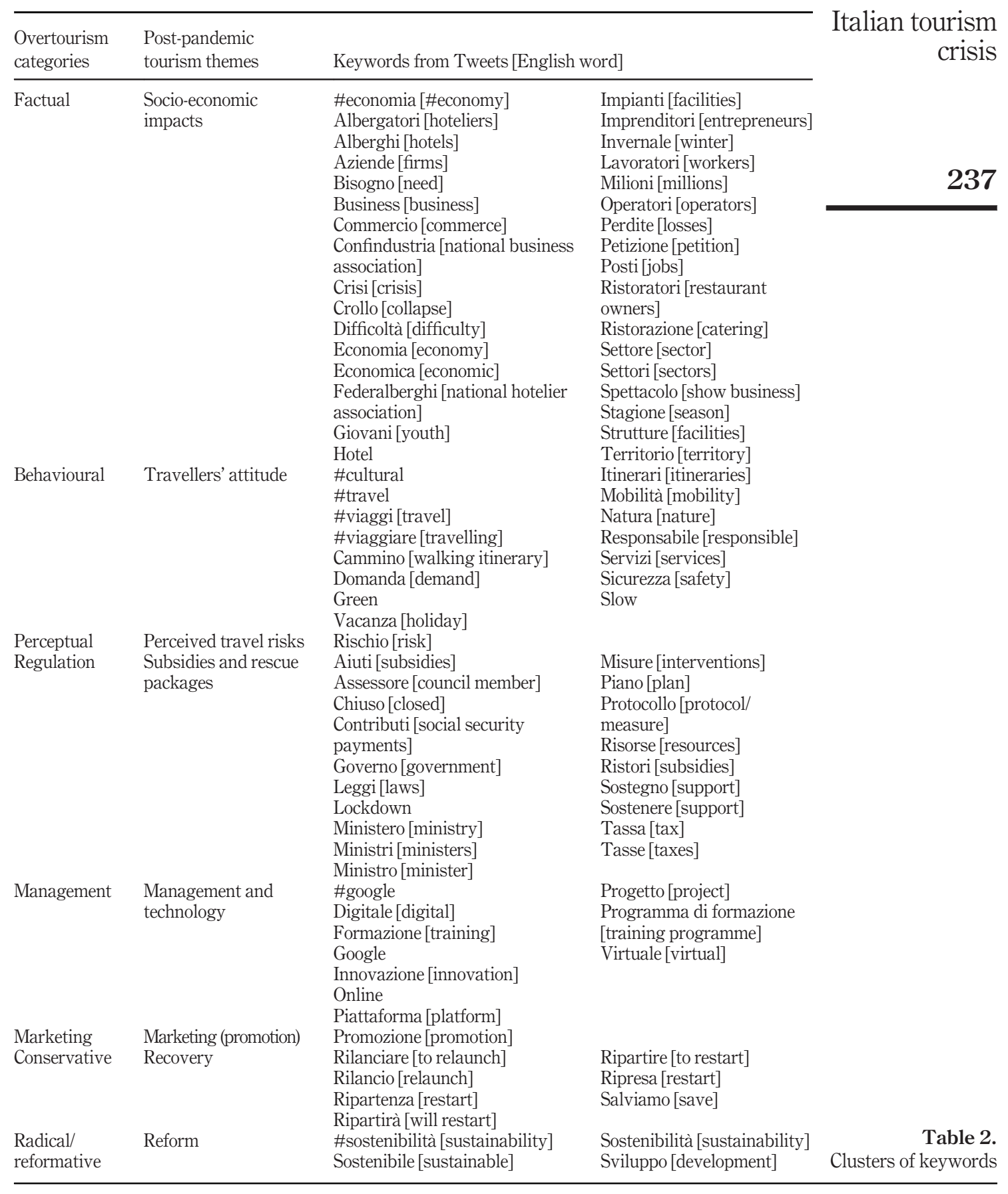




\section{JPMD \\ 15,3}

\section{8}

Figure 2.

Most frequent keywords in the Twitter debate

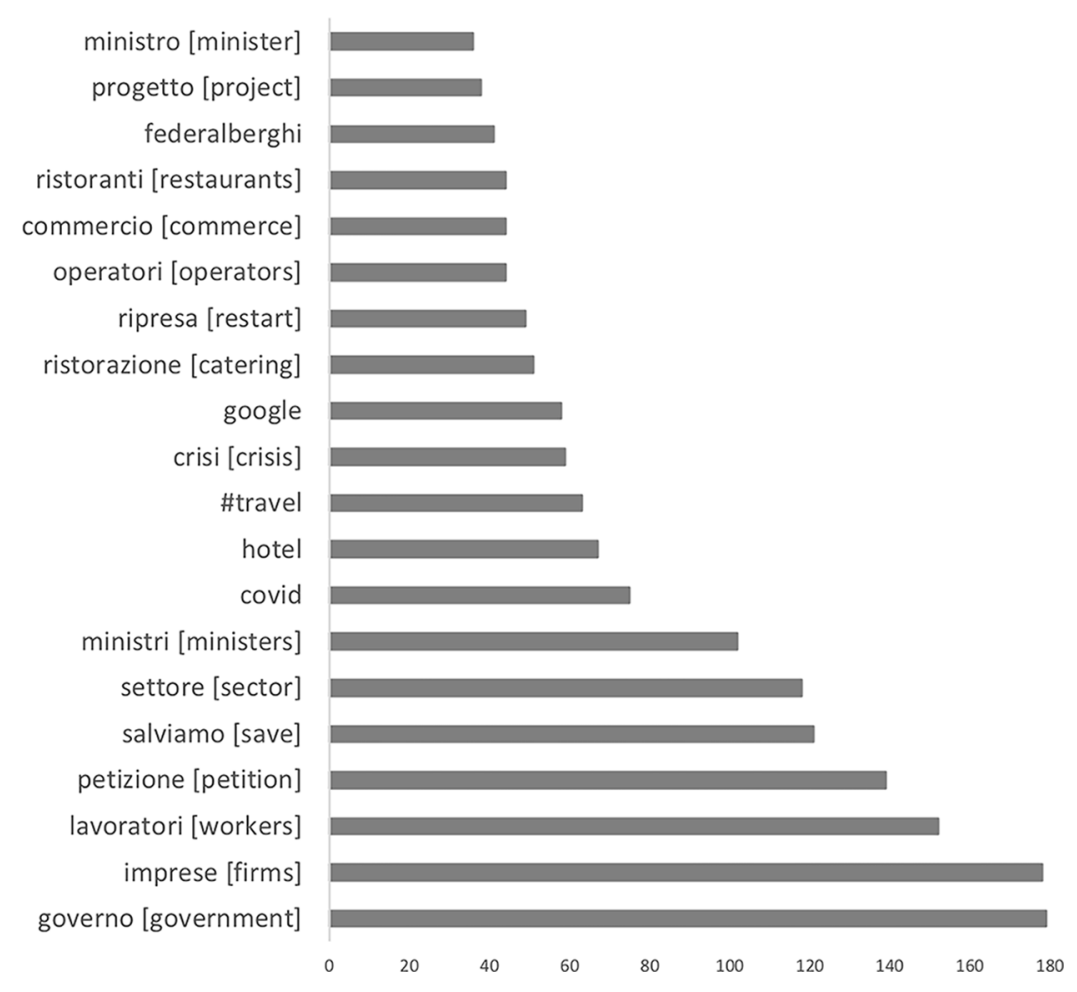

and emerged as a provider of a financial safety net for tourism businesses and workers, with an emphasis on the need for its rapid actions ("before it is too late") in an exceptional state of urgency, when the tourism industry was collapsing and a regulator defining support schemes but also restrictions, rules and standards for tourism facilities.

The recovery theme $(11 \%)$ prevailed over the reform one $(3 \%)$. Relaunching and restarting tourism was represented as the priority, together with the mission of "saving" tourism and the economy. Tourism positive impacts and its crucial role for local economies were in focus, including tourism significant contribution to the national labour market, generally characterised by high unemployment rates especially among young workers and women. Accordingly, much emphasis was on forms of support for tourism businesses to stand the crisis and on the priority of maintaining them alive ("tourism risks a desertification", as stated in a tweet).

Limited room for a critical perspective on tourism "as it was" was left, with an exception for those posts suggesting the need for investments to be prepared for future tourism (e.g. let's prepare for tourism restart by investing in training and education, Table 3). Although limited, the attention to tourism reforms did emerge from the analysis, centred on the idea of sustainability and sustainable development. Slow tourism, smart tourism and environmental sustainability were mentioned concerning the innovative projects to transform destinations and re-envision tourism development models (e.g. the project \#tourismofthefuture wants to transform tourism through six pillars: smart tourism, circular economy, energy efficiency, emission reduction, sustainable building sector, destination transformation, Table 3). 
Mentioned most

Government

After receiving technical reports, ski resort entrepreneurs wait for the validation of sanitary protocols by the government

Limited financial support and decreasing occupation. Baffled hospitality

entrepreneurs ask the government for urgent actions

In Sardinia another summer in crisis? Hotels: regional government is absent, rules are lacking

Incentives, tax cuts and new funds for tourism: real estate tax breaks, rental bonus, funds for culture: measures for tourism in the financial law looking forward to the Recovery Plan

Save Italian Presidency of the Councils of Ministers: Let's save tourism firms and workers,

Restart before it is too late

Let's save tourism business that have always represented a fantastic job market in

Italy

Together to restart and build present and future. . Tourism, culture, mobility, services and Tour de France 2024, Olympics 2032

Support for commerce, tourism and restaurants. Let's get to a safe restart as soon as possible

Tourism restart being the economic engine we all know

Digital laboratories to be prepare for a restart

Let's prepare for tourism restart by investing in training and education

Federalberghi

Petition

Workers

Firms

Google

Hotel

Project

Note: *Authors' own translation hospitality
Tourism, loss up to $80 \%$. Federalberghi proposals for the government: "Let's intervene before it is too late"

Federalberghi: a petition was sent to the government to save firms and workers, this morning 19,000 signatures were collected

Federalberghi approved a petition to ask the government to help tourism firms to survive until we get back to the normality

Google: with trend and big data tourism will restart in Italy

Google launches Hotel Insights in Italy, to support the tourism industry

Google rescuing hotels, launching Hotel Insights. A platform offering information, resources and visibility without costs to relaunch tourism and attract the demand, presented with MIBACT

Googles searches are changed in tourism. . . the traveller prefers domestic destinations and flexible and safe solutions

Google boosts the relaunch of Italian tourism: Hotel Insights is a platform for the

The walking route [cammino] project that in times of COVID transforms the slow tourism in new economy \#camminodioropa

Project Cammino d'Etruria ... more than $400 \mathrm{~km}$ for walking and mountain bike ... for a slow tourism

Deadline postponed for the submission of projects in the tourism sector and culture, within the project Renaissance Florence

The project \#tourismofthefuture wants to transform tourism through six pillars: smart tourism, circular economy, energy efficiency, emission reduction, sustainable building sector, destination transformation

Bike tourism is a great opportunity for a healthy, sustainable and innovative tourism, with significant revenues for the local system ... my commitment is to move the region towards this model
Table 3.

Examples of retrieved tweet fragments 


\section{JPMD \\ 15,3}

Figure 3.

Post-pandemic tourism themes

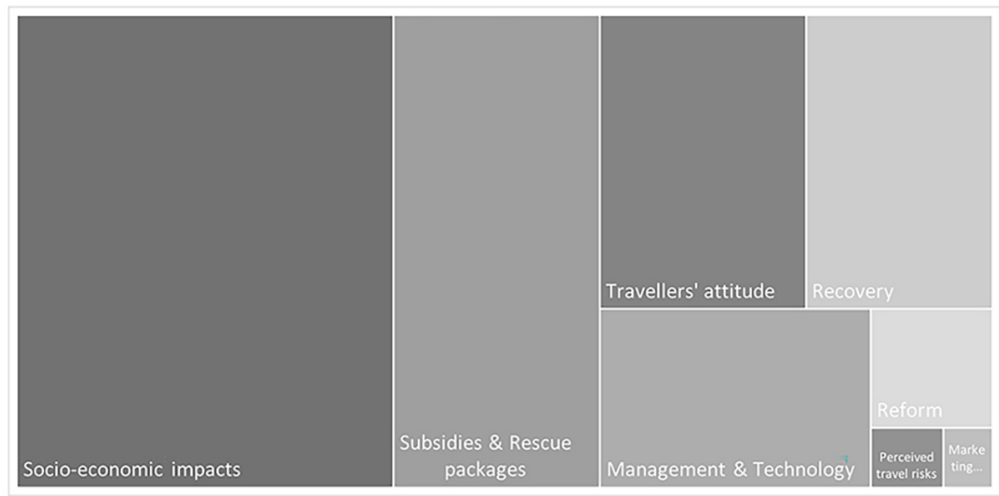

This "sustainable turn" was also supported by the travellers' attitude theme, which covered $12 \%$ of the analysed posts and suggested travellers' responsible behaviours and the need for innovative projects to respond to the emerging tourist preferences.

Management actions were discussed by $10 \%$ of analysed posts. Training programmes to improve competencies and skills, projects for redesigning tourism offering and digital technologies were in focus, with significant expectations on the big tech players, such as Google (various tweets spoke of the online event "Google for the Italian tourism"), and digital platforms. Concerning these components of the tourism discourse, the role of government, especially the national government, seemed to be fairly marginal, whereas other actors, such as banks, firms, associations (e.g. Movimento Lento for the Cammino di Oropa in Piedmont region, Table 3) and small local municipalities (e.g. Cammino d'Etruria, Table 3) were represented as central to the definition of transformative tourism projects. A global technology player, such as Google, is represented as crucial support for the whole industry, providing key digital levers for "a restart" (e.g. Hotel Insights, Table 3).

Perceived travel risks (1\% posts) and promotional actions $(1 \%)$ were part of the tourism discourse emerging from the analysis, although fairly marginal.

\section{Discussion}

A set of themes characterised the Italian tourism debate on Twitter, which provided the empirical ground to discuss the link between pre-COVID overtourism and post-pandemic tourism scenarios.

The integrative interpretative framework in Table 4 juxtaposes the empirical results from the online media debate on Twitter and the emerging issues in the COVID-19 literature, reconnecting them to the overtourism knowledge (i.e. analytical dimensions, actions and tourism development models).

The analytical dimensions of the overtourism knowledge - factual, behavioural and perceptual - cast light on significant aspects of post-pandemic tourism, highlighting continuities with the pre-pandemic overtourism debate. The socio-economic impacts, which are a relevant component of the COVID-19 research agenda (e.g. economic loss, social costs and effects on the real estate market), represented the factual dimension of the analysed media debate and helped identify tourism firms and workers as the passive actors in the post-pandemic turn, the victims of the crisis in need to be rescued.

Travellers' attitude and perceived travel risks, resulting from the online media debate and discussed in the post-pandemic tourism literature, are in continuity with the 


\begin{tabular}{|c|c|c|c|}
\hline $\begin{array}{l}\text { Online media } \\
\text { debate on Twitter }\end{array}$ & Emerging issues in the COVID-19 agenda & $\begin{array}{l}\text { Overtourism } \\
\text { knowledge }\end{array}$ & crisis \\
\hline $\begin{array}{l}\text { Socio-economic } \\
\text { impacts }\end{array}$ & $\begin{array}{l}\text { Economic loss (jobs and income); social costs; effects on } \\
\text { the real estate market }\end{array}$ & $\begin{array}{l}\text { Analytical dimension-- } \\
\text { factual }\end{array}$ & \\
\hline Travellers' attitude & $\begin{array}{l}\text { Travelling intention, risk aversion, changing transport } \\
\text { preferences, protective behaviour, loyalty towards } \\
\text { reputable "responsible" destinations }\end{array}$ & $\begin{array}{l}\text { Analytical dimension - } \\
\text { behavioural }\end{array}$ & 241 \\
\hline Travel risks & $\begin{array}{l}\text { Fears, negative feelings for crowding perceptions and } \\
\text { crowded environments, residents' fear and willing to pay } \\
\text { for risk reduction }\end{array}$ & $\begin{array}{l}\text { Analytical dimension- } \\
\text { perceptual }\end{array}$ & \\
\hline $\begin{array}{l}\text { Subsidies and rescue } \\
\text { packages }\end{array}$ & Stimulus package, incentives, subsidies & Actions - regulation & \\
\hline $\begin{array}{l}\text { Management and } \\
\text { technology }\end{array}$ & None & Actions - management & \\
\hline $\begin{array}{l}\text { Marketing } \\
\text { (promotion) }\end{array}$ & $\begin{array}{l}\text { Recovery marketing, destination media profiling, post- } \\
\text { crisis risk communication }\end{array}$ & Actions - marketing & \\
\hline Recovery & $\begin{array}{l}\text { Mitigation of impacts on the tourism system (to bounce } \\
\text { back), recovery approach }\end{array}$ & $\begin{array}{l}\text { Tourism development } \\
\text { model - conservative }\end{array}$ & Table 4 \\
\hline Reform & $\begin{array}{l}\text { "Prepare for tomorrow", "holistic and innovative } \\
\text { mindset", transformational opportunity, reform } \\
\text { approach; sustainable, ethical, responsible tourism }\end{array}$ & $\begin{array}{l}\text { Tourism development } \\
\text { model - radical/ } \\
\text { reformative }\end{array}$ & $\begin{array}{r}\text { An integrative } \\
\text { interpretative } \\
\text { framework }\end{array}$ \\
\hline
\end{tabular}

behavioural and perceptual dimensions of the overtourism knowledge. Travelling intention, risk aversion, changing transport preferences and loyalty towards reputable "responsible" destinations and, on the other side, fears, risk aversion and negative feelings connected with the perception of crowdedness, are not only in line with the pandemic crisis but they also echo the behavioural effects emerged in the overtourism literature.

Although to a limited extent for the short time of observations, both the analysed Twitter debate and the COVID-19 literature highlighted the relevance of regulative and marketing approaches of intervention, in line with the overtourism knowledge. Given the dramatic social and economic costs of the shrinking tourism economies in a phase of international and national constrained mobility, regulative actions were central in the online media debate, focussing on central government's subsidies and rescue packages as an immediate response to support and "save" the tourism industry, confirming previous findings in post-pandemic tourism literature (Foo et al., 2020).

Marketing and communication (including social media marketing) remained part of the post-pandemic tourism debate. In literature, there was an emphasis on post-crisis risk communication, recovery marketing and destination media profiling, whereas the online media debate did not pay significant attention to the role of marketing in post-pandemic tourism. The marketing potential to shape and shift the tourists' preferences towards more sustainable experiences (Font and McCabe, 2017), to rebrand the destinations (Seraphin et al., 2019a) and to build positive residents-tourists relationships (Seraphin et al., 2019 b), emerged in the pre-COVID, have so far remained overlooked in the post-COVID online media debate.

The managerial approach to action played a role in the analysed Twitter debate, while not being significantly covered in the emerging post-pandemic tourism literature. It is one key pillar of the overtourism knowledge and refers to those processes and organisational solutions that shape and give direction to destination development, innovating and redesigning tourism products without imposing normative schemes (limitation or incentive 
JPMD

15,3

\section{2}

schemes) (Koens et al., 2019; Pasquinelli and Trunfio, 2020b). To be noticed, the analysed Twitter debate stressed the important role of technology providers, banks, associations and small local municipalities in the definition of projects for tourism transformation.

That is, the analytical dimensions and actions - pillars of the overtourism knowledge made diverse actors emerge as protagonists of the post-pandemic tourism discourse and highlighted their active or passive roles. If tourism firms and workers are passive actors, hardly impacted by the crisis, national policymakers are represented as necessarily active actors, responsible for containing the socio-economic impacts of the crisis. The lack of rapid and effective policymakers' actions was represented as a concurrent cause of the tourism industry collapse. This also emerged from the online news media analysis of the debate on overtouristified destinations (Pasquinelli and Trunfio, 2020a).

Furthermore, at the local level, municipalities, associations and firms were represented as active proponents of potentially innovative projects boosting tourism change. That is, the overtourism knowledge allowed the identification of active and passive stakeholders and allowed reflecting on the blending of top-down and bottom-up approaches to addressing tourism imbalances and issues, with implications in terms of expanding tourism governance (Pasquinelli and Trunfio, 2020b).

The recovery-reform dichotomy, echoing the conservative-radical models from the overtourism knowledge, adds to this point by suggesting the coexistence of different actors adopting different rationales to shape their responses to the pandemic. A coherent discourse on top-down recovery emerged, intertwining the socio-economic impacts with regulative approaches to action, with the national government occupying a central and active position. The conservative view aiming at re-establishing the "business as usual" (Dwyer, 2017) and at triggering the bouncing-back of the tourism industry showed no concerns for the limitations and weaknesses of top-down public policies, in contrast with recent postpandemic tourism literature (Higgins-Desbiolles, 2021; Iannides and Gyimothy, 2020).

On the other hand, bottom-up approaches to reforming tourism emerged in combination with the search for sustainability and sustainable development as the only possible way out of the pandemic crisis, in line with post-pandemic tourism literature (Higgins-Desbiolles, 2021). A central role is assigned to local governments and private actors who engaged with tourism management projects from a bottom-up perspective. Investments in human capital formation, sustainable tourism experience design and digital infrastructure were represented as pivotal in framing tourism reforms.

\section{Conclusions}

This explorative study discussed the missing link between the overtourism knowledge and the emerging post-pandemic tourism scenarios, building on a conceptual and empirical investigation. It brings to light how the pre-pandemic literature on tourism sustainable development, focussing on overtourism, may provide the conceptual backbones for framing the post-pandemic tourism agenda. This overcomes the aerial views on post-COVID tourism phenomena that, observing the dramatic shrinkage of tourism flows in the global context, postulate an unbridgeable divergence between pre- and post-COVID tourism, between overtourism and "undertourism" eras.

Although acknowledging that the "unforeseen trajectories" raised doubts on the capacity of consolidated frameworks to explain tourism phenomena (Sigala, 2020), this paper discussed the opportunity to cross-fertilise former tourism knowledge and the emerging COVID-19 issues discussed in the literature to study and have a sense of orientation into post-pandemic tourism scenarios. 
The empirical analysis of the Italian debate on Twitter provided an insight into how post-COVID tourism "wicked problems" were framed, assuming that the online media debate mirrors and, at the same time, influences people's mindset and views on tourism and on how it should evolve. Beyond the surface of overtourism and post-pandemic tourism manifestations, which in most cases bring about numbers and issues of an opposite sign, the overtourism knowledge provided a meaningful framework for reaching novel insights into post-pandemic tourism dimensions, actions and models. Both in the pre- and post-COVID, there is a need to connect the outer layers of the tourism phenomenon, which are the factual, behavioural and perceptual dimensions and actions, with the underlying tourism models residing in the minds of tourism stakeholders. The online media analysis suggested that recovery and reform are not necessarily models in antithesis; instead, coexistence of different stakeholders' visions and scopes for action may occur in times of crisis.

The value of this conceptual effort is twofold. Firstly, the overtourism and post-pandemic tourism continuities invite not to forget the "evergreen" issues of tourism sustainable development, concerning the tourism industry's role, the conflicts and disequilibria that tourism necessarily boosts. In this regard, the academic debate achieved significant awareness and conceptual sophistication which should not be left behind in the post-COVID phase. New and upcoming challenges posed by the COVID-19 crisis have drawn attention to "old" concerns and inquiry on the underlying tourism models informing tourism stakeholders' (including policymakers') decision-making and actions. Bouncing back to consolidated tourism patterns and modalities (e.g. spaces, roles and goals) echoes the conservative approach to addressing tourism disequilibria, using impact mitigation that does not undermine established forms of tourism in their essence. On the other hand, bouncing forward to innovative and transformational tourism patterns and modalities echoes the radical rethinking of tourism models. This implies the construction and mobilisation of imaginative mindsets that re-envision the contribution of tourism to tourists', entrepreneurs' and the local communities' well-being, which is certainly not a novel challenge for both policymakers and scholars.

Secondly, forgetting what we learnt may lead to being blind in our analyses even in front of clear-cut manifestations of the "old" tourism mechanisms. Summer 2020, when the perceived contagion risk reduced, demonstrated the rapid and strong bouncing back of tourism arrivals in some destinations, not without overcrowding problems and old sustainability issues exacerbated by the novel health threat and the potential unsustainable pressure on local public health infrastructures.

Juxtaposing the adopted conceptual framework and the empirical results, three future research streams can be outlined. Firstly, the "recovery versus reform" dilemma (HigginsDesbiolles, 2021) needs to be addressed by going beyond the dualism mirroring the conservative versus radical approach from the overtourism knowledge. The analysis of the Italian debate demonstrated the strength of the recovery discourse, for the urgency of many firms and workers to cope with the deep and multi-headed COVID-19 crisis. Social issues related to unemployment and poverty are legitimately prioritised in the short term over the pursuit of innovation, transformation and sustainability in the long term. At the same time, signals of reformative views in the face of the pandemic crisis emerged from the online media debate. This suggested that turning the principles of sustainability into practices may imply combining recovery and reform, conservative and radical tourism models and reflecting on the different actors' vision and scope for action and their different yet potentially complementary roles (i.e. global, national and local actors, public and private actors). Efforts to reinterpret the recovery versus reform dilemma as a continuum of approaches and models may open a nuanced and pragmatic space for framing evolutionary 
$\mathrm{JPMD}$

15,3

tourism development in the post-pandemic. Scholars should not overlook this conceptual and policy challenge.

Research efforts should fill the emerging gap in the post-pandemic tourism literature on the managerial approaches, learning from and capitalising on the overtourism debate. In this regard, tourist dispersal strategies through the design of alternative tourism products (Peeters et al., 2018; UNWTO, 2018), tourist flows optimisation (Oklevik et al., 2019), infrastructure improvements to reduce tourist pressure (Koens, Potsma and Papp, 2018) and the process of favouring local employment and community engagement to reduce local conflicts (Postma and Schmuecker, 2017), discussed in the overtourism debate, may represent a useful starting point in the post-pandemic context. Managerial actions and tools in the post-pandemic may represent an opportunity for applied research to address the "old" challenge of putting the concept of sustainability into practice (Hunter, 1997; Garrod and Fyall, 1998).

Finally, a research agenda on the contribution of digital technologies to post-pandemic tourism deserves further theoretical and empirical efforts. If technology was said to be at the core of several solutions for the COVID-19 issues (Gretzel et al., 2020), much has to be done to critically engage with technologies and their support to tourism recovery and reform and to size the extent to which they can make a difference. The significant expectations and trust in technologies, suggested by the Twitter analysis, should be taken into account as an important variable in future studies.

Moreover, we should not forget the need - emerged about overtouristified destinations to entangle the technology deployment into broader frames of local sustainable development, where the technological, human and social dimensions need to be combined and integrated (Koens et al., 2019; Pasquinelli and Trunfio, 2020b).

The link between overtourism and post-pandemic tourism was built by this study, not without conceptual and empirical limitations. Although belonging to the long-standing sustainable tourism debate, the overtourism agenda did not reach significant maturity, and its fragmentation may limit its potential support to the post-COVID agenda. The empirical study focussed on a limited timeframe and multiple coring rounds into Twitter discussions might provide more nuanced insights into the debate. Different geographical contexts, then, may add meaningful insights, and comparative research may cast light on the tourism debate from diverse geographical and cultural perspectives.

\section{References}

Bank of Italy (2018), Il Peso Del Turismo in Italia, le Caratteristiche Della Domanda e la Capacità Ricettiva, Bank of Italy, Rome.

Brida, J.G., Cortes-Jimenez, I. and Pulina, M. (2014), "Has the tourism-led growth hypothesis been validated? A literature review", Current Issues in Tourism, Vol. 19 No. 5, pp. 1-37.

Bruns, A. and Burgess, J. (2012), "Researching news discussion on twitter: New methodologies", Journalism Studies, Vol. 13 Nos 5/6, pp. 801-814.

Capocchi, A., Vallone, C., Amaduzzi, A. and Pierotti, M. (2019), "Is 'overtourism' a new issue in tourism development or just a new term for an already known phenomenon?", Current Issues in Tourism, Vol. 23 No. 18, doi: 10.1080/13683500.2019.1638353.

Cheer, J.M., Milano, C. and Novelli, M. (2019), "Tourism and community resilience in the anthropocene: accentuating temporal overtourism", Journal of Sustainable Tourism, Vol. 27 No. 4, pp. 554-572, doi: 10.1080/09669582.2019.1578363.

Cheung, K.S. and Li, L.H. (2019), "Understanding visitor-resident relations in overtourism: developing resilience for sustainable tourism”, Journal of Sustainable Tourism, Vol. 27 No. 8, pp. 1197-1216, doi: 10.1080/09669582.2019.1606815. 
Collins-Kreiner, N. and Ram, Y. (2020), "National tourism strategies during the COVID-19 pandemic", Italian tourism Annals of Tourism Research, In press, doi: 10.1016/j.annals.2020.103076.

Colomb, C. and Novy, J. (Eds) (2017), Protest and Resistance in the Tourist City, Routledge.

crisis

de la Calle-Vaquero, M., Garcì-Hernàndez, M. and Mendoza de Miguel, S. (2020), "Urban planning regulations for tourism in the context of overtourism. Applications in historic centres", Sustainability, Vol. 13 No. 70, pp. 1-22.

De Moya, M. and Jain, R. (2013), "When tourists are your 'friends': exploring the brand personality of Mexico and Brazil on Facebook", Public Relations Review, Vol. 39 No. 1, pp. 23-29.

Dodds, R. and Butler, R.W. (Eds) (2019), Overtourism, Issues, realities and solutions, De Gruyter.

Dolnicar, S. and Zare, S. (2020), "COVID19 and airbnb - disrupting the disruptor”, Annals of Tourism Research, Vol. 83, p. 102961, doi: 10.1016/j.annals.2020.102961

Dwyer, L. (2017), "Saluting while the ship sinks: the necessity for tourism paradigm change", Journal of Sustainable Tourism, Vol. 26 No. 1, pp. 29-48.

Font, X. and McCabe, S. (2017), "Sustainability and marketing in tourism: its contexts, paradoxes, approaches, challenges and potential", Journal of Sustainable Tourism, Vol. 25 No. 7, pp. 869-883.

Foo, L.-P., Chin, M.-Y., Tan, K.-L. and Phuah, K.-T. (2020), "The impact of COVID-19 on tourism industry in Malaysia", Current Issues in Tourism, pp. 1-5, doi: 10.1080/13683500.2020.1777951.

Fotiadis, A., Polyzos, S. and Huan, T.-C. (2021), "The good, the bad and the ugly on COVID-19 tourism recovery”, Annals of Tourism Research, Vol. 87, p. 103117, doi: 10.1016/j.annals.2020.103117.

Garrod, B. and Fyall, A. (1998), "Beyond the rhetoric of sustainable tourism?", Tourism Management, Vol. 19 No. 3, pp. 199-212.

Goodwin, H. (2017), “The challenge of overtourism. Responsible tourism partnership”, Working Paper, 4 October 2017.

Gossling, S., Scott, D. and Hall, M. (2020), "Pandemics, tourism and global change: a rapid assessment of COVID-19", Journal of Sustainable Tourism, Vol. 29 No. 1.

Gretzel, U., Fuchs, M., Baggio, R., Hoepken, W., Law, R., Neidhardt, J., Pesonen, J., Zanker, M. and Xiang, Z. (2020), "e-Tourism beyond COVID-19: a call for transformative research", Information Technology and Tourism, Vol. 22 No. 2, pp. 187-203.

Hall, M.C. (2003), "Tourism issues, agenda setting and the media”, e-Review of Tourism Research, Vol. 1 No. 3, pp. $42-45$.

Hang, H., Aroean, L. and Chen, Z. (2020), "Building emotional attachment during COVID-19”, Annals of Tourism Research, Vol. 83, p. 103006, doi: 10.1016/j.annals.2020.103006.

Hassan, S.B. and Soliman, M. (2021), "COVID-19 and repeat visitation: assessing the role of destination social responsibility, destination reputation, holidaymakers' trust and fear arousal", Journal of Destination Marketing and Management, Vol. 19, p. 1-11.

Hays, S., Page, S.J. and Buhalis, D. (2013), "Social media as a destination marketing tool: its use by national tourism organisations", Current Issues in Tourism, Vol. 16 No. 3, pp. 211-239.

Higgins-Desbiolles, F. (2021), "The 'war over tourism': challenges to sustainable tourism in the tourism academy after COVID-19", Journal of Sustainable Tourism, Vol. 29 No. 4, pp. 551-569.

Higgins-Desbiolles, F., Carnicelli, S., Krolikowski, C., Wijesinghe, G. and Boluk, K. (2019), "Degrowing tourism: rethinking tourism”, Journal of Sustainable Tourism, Vol. 27 No. 12, doi: 10.1080/ 09669582.2019.1601732.

Hunter, C. (1997), "Sustainable tourism as an adaptive paradigm”, Annals of Tourism Research, Vol. 24 No. 4, pp. 850-867.

Iannides, D. and Gyimothy, S. (2020), "The Covid-19 crisis as an opportunity for escaping the unsustainable global tourism path", Tourism Geographies, Vol. 22, No. 3, pp. 624-632, doi: $10.1080 / 14616688.2020 .1763445$. 
ISTAT (2020), Movimento Turistico in Italia Gennaio-Settembre, ISTAT, Rome, Italy.

Johnston, E. (2020), “Outbreak turns Kyoto's overtourism into 'undertourism”, The Japan Times.

Karabulut, G., Bilgin, M.H., Demir, E. and Doker, A.C. (2020), "How pandemics affect tourism: International evidence", Annals of Tourism Research, Vol. 84, p. 102991.

Kock, F., Nørfelt, A., Josiassen, A., Assaf, A.G. and Tsionas, M.G. (2020), "Understanding the COVID-19 tourist psyche: the evolutionary tourism paradigm", Annals of Tourism Research, Vol. 85, p. 103053, doi: 10.1016/j.annals.2020.103053.

Koens, K., Postma, A. and Papp, B. (2018), "Is overtourism overused? Understanding the impact of tourism in a city context", Sustainability, Vol. 10 No. 12, p. 4384.

Koens, K., Melissen, F., Mayer, I. and Aall, C. (2019), "The smart city hospitality framework: creating a foundation for collaborative reflections on overtourism that support destination design", Journal of Destination Marketing and Management, doi: 10.1016/j.jdmm.2019.100376.

Lalicic, L., Huertas, A., Moreno, A. and Jabreel, M. (2020), "Emotional brand communication on Facebook and Twitter: are DMOs successful?”, Journal of Destination Marketing \& Management, Vol. 16 (June), pp. 1-11.

Li, J., Nguyen, T.H.H. and Coca-Stefaniak, J.A. (2021), “Coronavirus impacts on post-pandemic planned travel behaviours”, Annals of Tourism Research, Vol. 86 (January), pp. 1-5, doi: 10.1016/j. annals.2020.102964.

Matiza, T. (2020), "Post-COVID-19 crisis travel behaviour: towards mitigating the effects of perceived risk", Journal of Tourism Futures, Vol. ahead-of-print No. ahead-of-print, doi: 10.1108/JTF-042020-0063.

Milano, C. (2017), Overtoursim Y Turismofobia: Tendencias Globales y Contextos Locales, Barcelona.

Muler Gonzalez, V., Coromina, L. and Galí, N. (2018), "Overtourism: residents' perceptions of tourism impact as an indicator of resident social carrying capacity - case study of a Spanish heritage town", Tourism Review, Vol. 73 No. 3, doi: 10.1108/TR-08-2017-0138.

Novy, J. and Colomb, C. (2019), "Urban tourism as a source of contention and social mobilisations: a critical review", Tourism Planning and Development, Vol. 16 No. 4, pp. 358-375.

Oklevik, O., Gössling, S., Michael, H., Jacobsen, S., Kristian, J., Petter, G. and McCabe, S. (2019), "Overtourism, optimisation, and destination performance indicators: a case study of activities in fjord Norway", Journal of Sustainable Tourism, Vol. 27 No. 12, doi: 10.1080/ 09669582.2018.1533020.

Pasquinelli, C. and Trunfio, M. (2020a), "Overtouristified cities: an online news media narrative analysis", Journal of Sustainable Tourism, Vol. 28 No. 11, pp. 1805-1824.

Pasquinelli, C. and Trunfio, M. (2020b), "Reframing urban overtourism through the smart-city lens", Cities, Vol. 102 No. July, pp. 1-8.

Peeters, P.M., Gossling, S., Klijs, J., Milano, C., Novelli, M., Dijkmans, C.H.S., .. Postma, A. (2018), Research for TRAN Committee - Overtourism: impact and Possible Policy Responses, European Parliament, Policy Department for Structural and Cohesion Policies.

Phi, G.T. (2019), "Framing overtourism: a critical news media analysis", Current Issues in Tourism, pp. 1-5.

Postma, A. and Schmuecker, D. (2017), "Understanding and overcoming negative impacts of tourism in city destinations: conceptual model and strategic framework", Journal of Tourism Futures, Vol. 3 No. 2, pp. 144-156, doi: 10.1108/JTF-04-2017-0022.

Qiu, R.T.R., Park, J., Li, S. and Song, H. (2020), "Social costs of tourism during the COVID-19 pandemic", Annals of Tourism Research, Vol. 80, pp. 1-8.

Rasoolimanesh, S.M. and Jaafar, M. (2016), "Residents' perception toward tourism development: a pre-development perspective", Journal of Place Management and Development, Vol. 9 No. 1, pp. 1-23. 
Rasoolimanesh, S.M., Jaafar, M., Marzuki, A. and Abdullah, S. (2017), "Tourist's perceptions of crowding at recreational sites: the case of the Perhentian islands", Anatolia, Vol. 28 No. 1, pp. 41-51, doi: 10.1080/13032917.2016.1247288.

Rosenow, J.E. and Pulshipher, G.L. (1979), "Tourism the good, the bad, and the ugly".

Sánchez-Cañizares, S.M., Cabeza-Ramírez, L.J., Muñoz-Fernández, G. and Fuentes-García, F.J. (2020), "Impact of the perceived risk from COVID-19 on intention to travel", Current Issues in Tourism, Vol. 24 No. 7, pp. 1-15, doi: 10.1080/13683500.2020.1829571.

Schweinsberg, S., Darcy, S. and Cheng, M. (2017), "The agenda setting power of news media in framing the future role of tourism in protected areas", Tourism Management, Vol. 62, pp. 241-252.

Seraphin, H., Sheeran, P. and Pilato, M. (2018), "Over-tourism and the fall of Venice as a destination”, Journal of Destination Marketing and Management, Vol. 9, pp. 374-376, doi: 10.1016/j.jdmm.2018.01.011.

Seraphin, H., Gowreesunkar, V., Zaman, M. and Bourliataux-Lajoinie, S. (2019a), "Community based festivals as a tool to tackle tourismphobia and antitourism movements", Journal of Hospitality and Tourism Management, Vol. 39 (June), pp. 219-223, doi: 10.1016/j.jhtm.2018.12.001.

Seraphin, H., Zaman, M., Olver, S., Bourlinataux-Lajoinie, S. and Dosquet, F. (2019b), "Destination branding and overtourism”, Journal of Hospitality and Tourism Management, Vol. 38, pp. 1-4.

Sharma, A. and Nicolau, J.L. (2020), "An open market valuation of the effects of COVID-19 on the travel and tourism industry”, Annals of Tourism Research, Vol. 83, p. 102990, doi: 10.1016/j.annals.2020.102990.

Sigala, M. (2020), "Tourism and COVID-19: impacts and implications for advancing and resetting industry and research", Journal of Business Research, Vol. 117, pp. 312-321, doi: 10.1016/j.jbusres.2020.06.015.

Teye, V., Sirakaya, E. and F. Sönmez, S. (2002), "Residents' attitudes toward tourism development", Annals of Tourism Research, Vol. 29 No. 3, pp. 668-688, doi: 10.1016/S0160-7383(01)00074-3.

Trunfio, M. and Della Lucia, M. (2018), "Engaging destination stakeholders in the digital era: the best practice of Italian regional DMOs", Journal of Hospitality and Tourism Research, Vol. 43 No. 3, pp. 349-373.

Trunfio, M. and Pasquinelli, C. (2021), "Smart technologies in the COVID-19 crisis: managing tourism flows and shaping visitors' behaviours", European Journal of Tourism Research, Forthcoming, Vol. 29, pp. 1-20.

UNWTO (2018), “Overtourism?”, Understanding and Managing Urban Tourism Growth beyond Perceptions.

Yeh, S.S., Wai Aliana, L.M. and Zhang, F.Y. (2012), "Visitors' perception of theme park crowding and behavioral consequences", Advances in Hospitality and Leisure, Vol. 8, pp. 63-83.

Zhang, H., Song, H., Wen, L. and Liu, C. (2020), "Forecasting tourism recovery amid COVID-19", Annals of Tourism Research, Vol. 87, p. 1-16, doi: 10.1016/j.annals.2021.103149.

Zheng, D., Luo, Q. and Ritchie, B.W. (2021), "Afraid to travel after COVID-19? Self-protection, coping and resilience against pandemic 'travel fear", Tourism Management, Vol. 83, p. 104261.

\section{About the authors}

Cecilia Pasquinelli, Assistant Professor in Management at the University of Naples "Parthenope" (Italy). Main research fields: place branding, place marketing, destination management, urban tourism, sustainable tourism. Cecilia Pasquinelli is the corresponding author and can be contacted at: cecilia.pasquinelli@uniparthenope.it

Mariapina Trunfio, Associate Professor and Director of the Master in Tourism \& Hospitality Management, University of Naples "Parthenope" (Italy). Main research fields: tourism innovation, immersive technologies, sustainability, cultural heritage, place branding and social media.

For instructions on how to order reprints of this article, please visit our website:

www.emeraldgrouppublishing.com/licensing/reprints.htm

Or contact us for further details: permissions@emeraldinsight.com 